\title{
Occurrence of Ahasverus advena (Coleoptera: Silvanidae) in corn grains from the city of Plácido de Castro, state of Acre, Brazil
}

\section{Ocorrência de Ahasverus advena (Coleoptera: Silvanidae) em grãos de milho provenientes de Plácido de Castro, Acre, Brasil}

\author{
Adalberto Hipólito de Sousa ${ }^{1, *}$ (1) (https://orcid.org/0000-0002-3089-2762) \\ Davair Lopes Teixeira Júnior ${ }^{1}$ (1) (https://orcid.org/0000-0001-5051-9255) \\ Josilene Ferreira Rocha' (1) (https://orcid.org/0000-0003-3895-8903) \\ Lucas Martins Lopes ${ }^{1}$ (i) (https://orcid.org/0000-0001-7686-4997)
}

\begin{abstract}
Ahasverus advena (Coleoptera: Silvanidae) is a secondary pest of stored grains. It is a polyphagic and cosmopolitan species, with little information about its occurrence in the northern region of Brazil. This study was conducted to report the first occurrence of $A$. advena in corn grains in the city of Plácido de Castro, in the state of Acre, Brazil. In June 2019, the presence of $A$. advena under development was observed in a mass of corn grains. The identification was made at the species level using the available dichotomous keys. Since this is the first record of $A$. advena in corn grains in the city of Plácido de Castro, monitoring insects in the mass of corn grains is necessary to prevent the economic damages caused by $A$. advena to grains.
\end{abstract}

KEYWORDS: foreign grain beetle; fungivorous beetle; Zea mays; storage; South-Western Amazon.
RESUMO: Ahasverus advena (Coleoptera: Silvanidae) é uma praga secundária de grãos armazenados. É uma espécie polifágica e cosmopolita, com poucas informaçóes sobre sua ocorrência na região norte do Brasil. Este estudo tem o objetivo de relatar a primeira ocorrência de $A$. advena em grãos de milho na cidade de Plácido de Castro, Acre, Brasil. Em junho de 2019, observou-se a presença de $A$. advena desenvolvendo em uma massa de grãos de milho. A identificação foi feita a nível de espécie com a utilização das chaves dicotômicas disponíveis. Como este é o primeiro registro de $A$. advena em grãos de milho na cidade de Plácido de Castro, o monitoramento dos insetos na massa de grãos de milho é necessário para evitar danos econômicos causados por $A$. advena nos grãos.

PALAVRAS-CHAVE: besouro-de-grão-estrangeiro; besouro fungívoro; Zea mays; armazenamento; Amazônia Sul-Ocidental. 
Brazil is prominent in the world as one of the largest grain producers, having a record crop estimated at 250.5 million metric tons in the 2019/2020 season, which represents a growth of $3.5 \%$ compared to the 2018/2019 season (CONAB, 2020). However, high losses of grains during the storage stage are primarily associated with the attack of insect pests (Insecta: Coleoptera and Lepidoptera), which are widely distributed in several regions, especially due to the transportation of processed and industrialized grains and products (FARONI; SOUSA, 2006; HAGSTRUM et al., 2013).

In this research, the occurrence of Ahasverus advena (Waltl, 1834) [= Cryptophagus advena] (Coleoptera: Silvanidae) was first recorded in a mass of grains from the city of Plácido de Castro, in the state of Acre, Brazil. In general, pest attack on stored grains causes physical and physiological deterioration of grains and seeds as well as qualitative losses, including the reduction of nutritional value, resulting in economic damage or even total loss of the product (LORINI et al., 2015; PARASIAN et al., 2018).

The foreign grain beetle $A$. advena is a small red-brown beetle (Fig. 1). It is approximately $2-3 \mathrm{~mm}$ long. Its pronotum shape is broader than long, and it has distinctly curved and slightly serrated lateral margins. The front corners of the pronotum have distinct tooth-like lobes (PEREIRA; SALVADORI, 2006; NAVARRO; NAVARRO, 2018). The larvae are worm-like, cream-colored, and reach a length of about $3 \mathrm{~mm}$ before becoming darker adults (PIERCE et al.,1991; LAILTON et al., 2018).

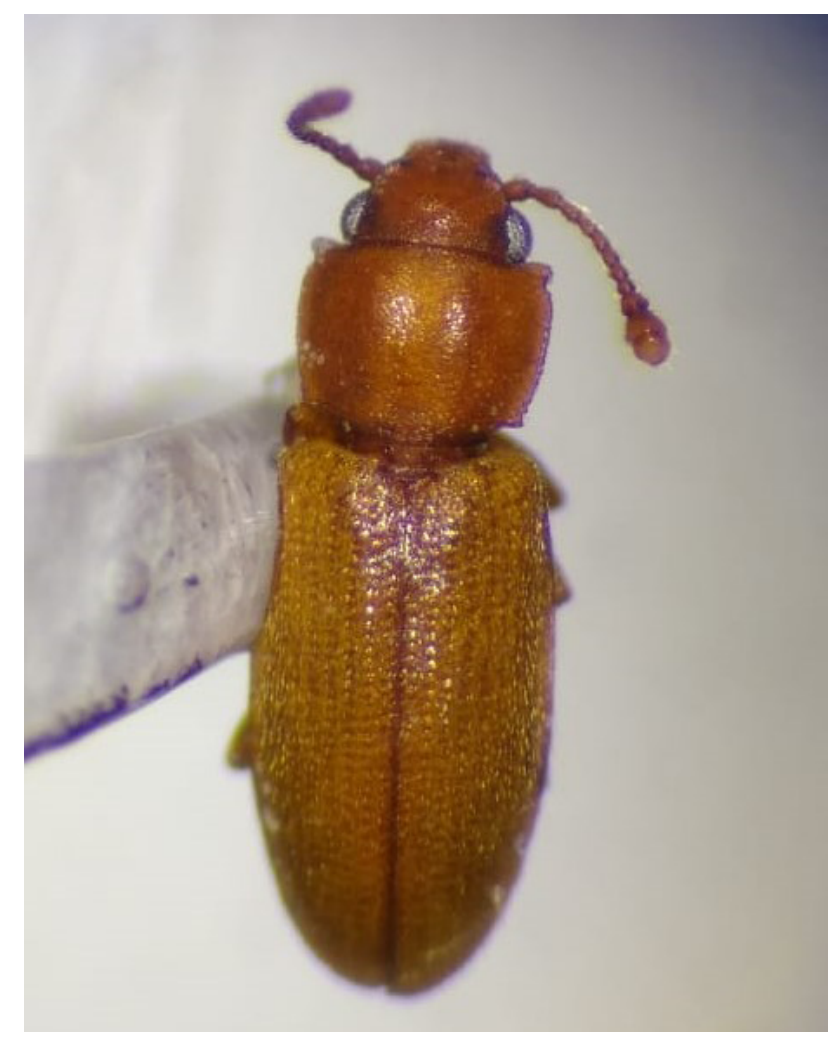

Figure 1. Dorsal view of Ahasverus Advena.
Ahasverus advena is a cosmopolitan pest of American, Ethiopian, or Eastern origin. It is widely distributed in Africa, Asia and the Middle East, Central America and the Caribbean, Europe, North America and Mexico, Oceania, and South America (HAGSTRUM et al., 2013). Although it is primarily a fungivorous beetle, it cannot be classified entirely as a mold feeder, but nutrients in mold are necessary to improve an otherwise inadequate diet (HILL, 1965; JACOB, 1996). It infests a wide variety of food products, usually under conditions of high humidity or when mold growth occurs (REES, 2007). According to HAGSTRUM et al. (2013) and PARASIAN et al. (2018), infestations of $A$. advena have been found in cocoa beans, peanuts, wheat, wheat flour, wheat germ, oat flakes, soy bran, and dried insects.

In June 2019, a large infestation by $A$. advena was observed in a mass of corn grains from the city of Plácido de Castro, in the state of Acre, Brazil (10 $10^{\circ} 02^{\prime \prime} S$ and $\left.67^{\circ} 11^{\prime} 18^{\prime \prime W}\right)$. A sample was collected and placed in $1.8 \mathrm{~L}$ clear glass jars, which were kept under constant conditions of temperature $\left(27 \pm 2{ }^{\circ} \mathrm{C}\right)$ and relative humidity $(70 \pm 5 \%)$ and a scotophase of $24 \mathrm{~h}$.

After multiplication and observation, the insects were mounted with entomological pins on white cardboard triangles of 2 by $6 \mathrm{~mm}$ (double mounting). Three triangles were placed on a pin, containing one specimen of the species in the ventral, dorsal, and lateral positions.

The identification was made at the species level using the available dichotomous keys. The dry insects, fixed on pins, duly identified with information on the date and place of collection and the name of the collector, were accommodated in an entomological MDF box with a glass lid and a Styrofoam-coated bottom, treated with naphthalene as a preservative. The material went through the entire curatorial process (CAMARGO et al., 2015) and was deposited in the Entomological Collection of the Entomology Laboratory of the Federal University of Acre.

Studies have indicated that $A$. advena requires a nutrient found in mold and dry yeast to grow, and it can be found in pure cultures of various fungi (DAVID et al., 1974). Since they only colonize moist and moldy products and require high relative humidity conditions to grow and develop, these beetles are good indicators of poor storage conditions and spoiled food (JACOB, 1996; ZHAO et al., 2018).

The first step to solve any agricultural pest problem is directly linked to species identification (CUI et al., 2020). Once the scientific name of the insect is known, it is possible to obtain all bibliographic information about it (PEREIRA; SALVADORI, 2006). Discovering any insect attacks at the beginning of the infestation is extremely important to control the pest and preserve the quality of the grains, especially attacks from insects of great economic importance, such as some pests that do not yet have their occurrence recorded (NOURI et al., 2019). 
Since this is the first record of $A$. advena in a grain mass in Plácido de Castro, monitoring these insect pests in stored corn grains is recommended to alleviate the risks of the development of large colonies and to prevent economic damage. Furthermore, greater attention should be paid to the proper drying of corn grains to about $13 \%$ moisture content (wet base), thus preventing the formation of fungal colonies, with which the presence of A. advena, among other pests, is usually associated.

ACKNOWLEDGEMENTS: Not applicable.

FUNDING: This work did not receive any specific grant from funding agencies in the public, commercial, or not-for-profit sectors.

CONFLICTS OF INTEREST: All authors declare that they have no conflict of interest.

ETHICAL APPROVAL: Not applicable.

AVAILABILITY OF DATA AND MATERIAL: Data sharing not applicable to this article as no datasets were generated or analyzed during the current study.

AUTHORS' CONTRIBUTIONS: Conceptualization: Sousa, A.H. Investigation: Sousa, A.H.; Teixeira Júnior, D.L.; Rocha, J.F.; Lopes, L.M. Validation: Sousa, A.H.; Lopes, L.M.; Writing - original draft: Sousa, A.H.; Teixeira Júnior, D.L. Writing - review \& editing: Sousa, A.H.; Teixeira Júnior, D.L.; Rocha, J.F.; Lopes, L.M.

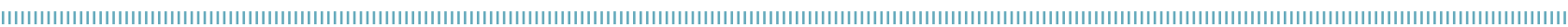
REFERENCES

CAMARGO, A.J.A.; OLIVEIRA, C.M.; FRIZZAS, M.R.; SONODA, K.C.; CORRÊA, D.C.V. Coleções entomológicas: legislação brasileira, coleta, curadoria e taxonomia para as principais ordens. Brasília: Embrapa, 2015. 117p. Disponível em: https://ainfo.cnptia. embrapa.br/digital/bitstream/item/122542/1/amabilio-01. pdf. Acesso em: 10 jul. 2020.

Companhia Nacional de Abastecimento (CONAB). Acompanhamento da safra 2019/2020 - $9 \circ$ levantamento de grãos. Brasília: Conab, 2020. 65p. Available from: https://www.conab.gov.br/info-agro/ safras/graos/boletim-da-safra-de-graos/item/download/32042_9 10765 cf5dc2d088c377e32cdef6fc72. Access on: 15 Jun. 2020.

CUI, J.; SU, Y.; FENG, S.; WEI, P.; LIU, X.; LI, Z. Morphological and molecular identification of Liposcelis corrodens (Heymons, 1909) (Psocodea: Liposcelididae) as the first record from China. Journal of Stored Products Research, Amsterdam, v.87, p.101588, 2020. https://doi.org/10.1016/j.jspr.2020.101588

DAVID, M.H.; MILLS, R.B.; SAUER, D.B. Development and oviposition of Ahasverus advena (Waltl) (Coleoptera, Silvanidae) on seven species of fungi. Journal of Stored Products Research, Amsterdam, v.10, n.1, p.17-22, 1974. https://doi. org/10.1016/0022-474X(74)90025-3

FARONI, L.R.D.; SOUSA, A.H. Aspectos biológicos e taxonômicos dos principais insetos-praga de produtos armazenados. In: ALMEIDA, F.A.C.; DUARTE, M.E.M.; MATA, M.E.R.M.C. (eds). Tecnologia de armazenagem em sementes. Campina Grande: UFCG, 2006. chap.7, p.371-402.
HAGSTRUM, D.W.; KLEJDYSZ, T.; SUBRAMANYAM, B.; NAWROT, J. Stored-product mites. In: Atlas of storedproduct insects and mites. Saint Paul: AACC International, 2013. 533-575p. Chap. 6. https://doi.org/10.1016/ B978-1-891127-75-5.50009-5

HILL, S.T. Axenic culture of the foreign grain beetle, Ahasverus advena (Waltl) (Coleoptera: Silvanidae) and the role of fungi in its nutrition. Bulletin of Entomological Research, Cambridge, v.55, n.4, p.681-690, 1965. https://doi.org/10.1017/ S0007485300049786

JACOB, T.A. The effect of constant temperature and humidity on the development, longevity and productivity of Ahasverus advena (Waltl) (Coleoptera: Silvanidae). Journal of Stored Products Research, Amsterdam, v.32, n.2, p.1 15-121, 1996. https://doi. org/10.1016/0022-474X(96)00011-2

LAILTON, L.A.; CONSTANTINO, L.M. BENAVIDES, P. Predatory capacity of Cathartus quadricollis and Ahasverus advena (Coleoptera: Silvanidae) on Hypothenemus hampei (Coleoptera: Curculionidae) under laboratory conditions. Revista Colombiana de Entomología, Cali, v.44, n.2, p.200-205, 2018.

LORINI, I.; KRZYZANOWSKI, F.C.; FRANÇA-NETO, J.B.; HENNING, A.A.; HENNING, F.A. Manejo Integrado de Pragas de Grãos e Sementes Armazenadas. Brasília: Embrapa, 2015. $81 \mathrm{p}$. Available from: https://ainfo.cnptia.embrapa.br/digital/ bitstream/item/129311/1/Livro-pragas.pdf. Access on: 10 Jul. 2020. 
NAVARRO, S.; NAVARRO, $\mathrm{H}$. Insect Pest management of oilseed crops, tree nuts and dried fruits. In: ATHANASSIOU, C.G.; ARTHUR, F.H. (eds). Recent advances in stored product protection. Berlin: Springer, 2018. chap.6, p.99-141. https:// doi.org/10.1007/978-3-662-56125-6_6

NOURI, B.; FOTOUHI, K.; MOHTASEBI, S.S.; NASIRI, A.; GOLDANSAAZ, S.H. Detection of different densities of Ephestia kuehniella pest on white flour at different larvae instar by an electronic nose system. Journal of Stored Products Research, Amsterdam, v.84, p.101522, 2019. https://doi.org/10.1016/j. jspr.2019.101522

PARASIAN, F.; TRISYONO, Y.A.; MARTONO, E. Resistance of Ahasverus advena and Cryptolestes ferrugineus to phosphine on imported cocoa beans from Cameroon, Ivory Coast and Dominican Republic. Jurnal Perlindungan Tanaman Indonesia, Yogyakarta, v.22, n.2, p.173-180, 2018. https://doi. org/10.22146/jpti.25769
PEREIRA, P.R.V.S.; SALVADORI, J.R. Identificação dos principais Coleoptera (Insecta) associados a produtos armazenados. Documentos Online 75. Passo Fundo: Embrapa Trigo, 2006. 28p. Available from: http://www.cnpt.embrapa.br/biblio/do/p_do75. htm. Access on: 10 Jul. 2020.

PIERCE, A.M.; PIERCE JUNIOR, H.D.; OEHLSCHLAGER, A.C.; BORDEN, J.H. 1-Octen-3-ol, attractive semiochemical for foreign grain beetle, Ahasverus advena (Waltl) (Coleoptera: Cucujidae). Journal of Chemical Ecology, Pennsylvania, v.17, n.3, p.567-580, 1991. https://doi.org/10.1007/BFO0982127

REES, D. (ed.). Insects of Stored Grain: A Pocket Reference. Clayton: CSIRO Publishing, 2007.77p. https://doi.org/10.1071/9780643094673

ZHAO, X.; WANG, D.; FIELDS, P.G.; LI, H. Effect of aflatoxin B 1 on development, survival and fecundity of Ahasverus advena (Waltl). Journal of Stored Products Research, Amsterdam, v.77, p.255-230, 2018. https://doi.org/10.1016/j.jspr.2018.04.005 